\title{
MENJADIKAN PARA SISWA AKTIF BERTANYA DALAM KELAS MATEMATIKA BERDASARKAN KURIKULUM 2013
}

\section{MAKE STUDENTS ACTIV IN MATHEMATICS LEARNING BASED ON CURICULUM 2013}

\author{
Mohammad Tohir \\ Mahasiswa S2 Pendidikan Matematika Pascasarjana Universitas Jember \\ dan Guru SMPN 2 Jember \\ matematohir@gmail.com
}

\begin{abstract}
Abstrak
Penggunaan pendekatan saintifik dalam pembelajaran matematika masih mengalami kendala dalam mewujudkannya, terutama yang dikeluhkan oleh para guru pada bagian kegiatan bertanya. Bahkan dalam praktiknya, sebagian besar guru menerapkan kurukulum 2013 semi KTSP. Hal ini tidak sejalan dengan apa yang diinginkan oleh pemerintah. Oleh karena itu, melalui artikel ini penulis akan sedikit mengupas tentang bagaimana cara agar para siswa aktif bertanya dalam setiap kegiatan pembelajaran matematika. Di dalam artikel ini penulis mengemukakan tentang temuan dari duakali hasil penelitian di dua instansi yang berbeda, yaitu ada enam point utama yang harus diketahui dan dipahami oleh guru dan ada sembilan point khusus yang harus dilakukan oleh guru dalam kegiatan bertanya. Penulis menyimpulkan bahwa untuk menjadikan para siswa aktif bertanya dalam kelas matematika, guru perlu membuat kegiatan pengamatan yang menarik berdasarkan kondisi sekolahnya masing-masing dan dalam kegiatan bertanya guru perlu melakukan sembilan point khusus tersebut. Selain hal tersebut, penulis mengemukakan secara lebih detail tentang pendekatan saitifik, contoh kegiatan pengamatan yang menarik dan model-model pembelajaran yang disarankan dalam Kurikulum 2013.
\end{abstract}

Kata-kata Kunci: Kurikulum 2013, Matematika, Pendekatan Saintifik

\section{Pendahuluan}

Penerapakan Kurikulum 2013 telah resmi diluncurkan oleh Pemerintah sejak tahun 2013. Beberapa sekolah telah dijadikan sekolah sasaran dan para Guru yang bersangkutan telah diikutkan pelatihan, baik Guru Matematika, Guru IPA, Guru IPS, Guru Bahasa Indonesia, Guru Bahasa Inggris, Guru PPKn, maupun Guru Penjaskes. Bahkan buku-buku pegangan siswa dan guru sudah beberapa kali direvisi sejak tahun 2014 sampai tahun 2016 ini. Akan tetapi tidak cukup hanya sampai disitu untuk mensukseskan Kurukum 2013, salah satu yang paling pokok dalam mensukseskan Kurikulum 2013 adalah penggunaan pendekatan saintifik dalam pembelajaran.

Setelah beberapa tahun terakhir ini dalam menggunakan pendekatan saintik juga mengalami kendala dalam prakteknya di lapangan, salah satu yang dikeluhkan oleh para guru adalah pada bagian "kegiatan bertanya". Padahal Salah satu alasan dipilihnya pendekatan saintifik sebagai pendekatan dalam Kurikulum 2013 adalah meningkatkan kemauan dan kemampuan bertanya para siswa di kelas.

Memang, membuat pertanyaan yang baik itu bukanlah suatu hal yang mudah. Seringkali kita membuat soal dengan sebegitu berhati-hatinya, akan tetapi siswa dengan mudahnya menjawab dengan jawaban yang belum tentu sesuai dengan yang kita harapkan. Oleh sebab itu, guru dituntut untuk pandai memotivasi siswa bertanya dan menjawab dengan benar. Pertanyaan yang diajukan sebaiknya beragam. Selain memiliki bobot mudah, sedang, dan sulit, pertanyaan juga harus bervariasi yang dapat menunjukkan tingkat berpikir seseorang. Menurut Taksonomi Bloom Revisi (Bloom and Krathwohl, 1965; dalam Morgan dan Saxton, 2006) 


\section{0 | Prosiding Seminar Nasional Matematika dan Pembelajarannya \\ Program Studi Pendidikan Matematika FKIP Universitas Jember, 23 Oktober 2016 \\ ISBN: 987-602-18397-4-4}

menjelaskan bahwa jenis-jenis pertanyaan siswa dapat dikelompokkan berdasarkan jenjang pada dimensi proses kognitif, yaitu meliputi mengingat (C1), memahami (C2), mengaplikasikan (C3), menganalisis (C4), evaluasi (C5), dan membuat/create (C6). Pada tingkatan mengingat, pertanyaan siswa menghendaki jawaban yang bersifat hafalan atau ingatan. Pada tingkatan pemahaman, pertanyaan siswa menghendaki jawaban yang bersifat pemahaman dengan kata-kata sendiri. Pada tahapan aplikasi, pertanyaan siswa berkaitan dengan bagaimana cara menerapkan suatu pelajaran yang telah ia dapat ke kehidupan nyata. Pada tingkatan analisis, pertanyaan siswa berupa pendapatnya tentang suatu pelajaran. Pada tingkatan evaluasi, pertanyaan-pertanyaan yang dilontarkan siswa berupa evaluasi hasil belajar mereka di kelas. Pada tingkatan membuat atau create adalah menggabungkan beberapa unsur menjadi suatu bentuk kesatuan. Pertanyaan tersebut berkaitan dengan bagaimana menghubungkan beberapa informasi dan pengetahuan yang telah ia dapat untuk menyelesaikan suatu masalah atau untuk menciptakan pengetahuan yang baru.

Ada beberapa hal yang harus diperhatikan dalam mengajukan pertanyaan kepada siswa (Suwardi, 2007:138). Yaitu:

\section{Maksud Pertanyaan}

Pertanyaan yang diajukan oleh guru dapat dimaksudkan untuk:

1) Meningkatkan minat belajar siswa.

Maksudnya pertanyaan yang diajukan oleh guru diharapkan dapat memunculkan rasa ke ingin tahuan siswa. Biasanya pertanyaan yang demikian ini dilakukan pada saat membuka dan menutup pelajaran, meskipun dapat juga dilakukan pada saat penyampaian materi.

2) Meningkatkan perhatian siswa terhadap suatu permasalahan.

Agar siswa terfokus pada materi yang diajarkan, biasanya guru mengajukan pertanyaan sebagai cara untuk meningkatkan perhatian siswa pada materi yang akan atau sedang diajarkan.

3) Mengembangkan pembelajaran aktif learning.

Pertanyaan yang diajukan oleh guru dapat dimaksudkan sebagai cara mengaktifkan siswa dalam proses pembelajaran. Cara yang demikian ini, dalam metode pembelajaran disebut metode Tanya jawab.

4) Mendiagnosis kesulitan belajar.

Mendiagnosis kesulitan belajar adalah menganalisis suatu kondisi yang dapat menyebabkan terhambatnya pencapaian tujuan pembelajaran. Salah satu caranya, guru dapat mengajukan pertanyaan kepada siswanya. Apabila pertanyaan tersebut tidak dapat dijawab oleh siswanya, guru dapat menyimpulkan bahwa siswa mengalami kesulitan belajar.

5) Mengetahui tingkat kemampuan siswa.

Pertanyaan yang diajukan oleh guru dapat dimaksudkan untuk mengukur tingkat kemampuan siswanya. Untuk maksud ini, pertanyaan dapat diajukan pada awal, tengah maupun akhir pembelajaran.

6) Memberi kesempatan kepada siswa untuk mengemukakan pertanyaannya.

Pertanyaan yang diajukan oleh guru dapat dimaksudkan untuk memberikan kesempatan kepada siswa agar dapat mengemukakan pendapat dan pandangannya. Pertanyaan yang demikian ini penting untuk melatih keberanian siswa dalam mengemukakan pendapatnya. Degan demikian guru mudah mengarahkan pendapat dan pandangan siswa untuk disesuaikan dengan tujuan pembelajarannya.

\section{Sikap Bertanya}

Pada saat mengajukan pertanyaan perlu dilakukan dengan sikap yang baik dan benar. Hal ini akan tercapai, apabila pada saat mengajukan pertanyaan guru memperhatikan norma yang berlaku dan menghargai harkat dan martabat siswa. Guru dalam mengajukan pertanyaan tidak boleh pilih kasih. Misalnya, guru hanya mengajukan pertanyaan kepada siswa yang pandai saja atau siswa yang kurang pandai saja atau siswa yang dikenal saja atau siswa yang duduk di depan saja. Sikap yang demikian ini akan menjadikan siswa merasa iri.

Sikap lain yang perlu diperhatikan guru adalah perhatian dan kedekatan. Sikap ini dapat ditunjukkan dengan cara Oleh sebab itu, guru harus berusaha mengajukan pertanyaan secara menyebar. Selain itu, pada saat mengajukan pertanyaan harus menggunakan bahasa yang baik dan sopan. Maksudnya guru tidak boleh menggunakan bahasa yang terkesan mengejek, mendekati tempat duduk, menyebutkan nama siswa, 
memperhatikan jawaban siswa, menatap wajah siswa, memberi pujian kepada siswa. Sikap yang demikian ini akan mendekatkan hubungan psikologis guru dengan siswanya.

Sedangkan proses pembelajaran Kurikulum 2013 pada Pendidikan Dasar dan Menengah telah diatur melalui Peraturan Menteri Pendidikan dan Kebudayaan Nomor 103 Tahun 2014 beserta lampirannya (Pedoman Pelaksanaan Pembelajaran). Dalam lampiran Peraturan Menteri tersebut dinyatakan tentang konsep dasar mengenai proses pembelajaran yaitu bahwa peserta didik dipandang sebagai subjek yang memiliki kemampuan untuk secara aktif mencari, mengolah, mengkonstruksi, dan menggunakan pengetahuan. Sejalan dengan pandangan tersebut, pembelajaran harus berkenaan dengan kesempatan yang diberikan kepada peserta didik untuk mengkonstruksi pengetahuan dalam proses kognitifnya. Selanjutnya, agar benar-benar memahami dan dapat menerapkan pengetahuan, peserta didik perlu didorong untuk bekerja memecahkan masalah, menemukan segala sesuatu untuk dirinya, dan berupaya keras mewujudkan ide-idenya.

Berdasarkan konsep dasar tersebut sejumlah prinsip pembelajaran dirumuskan sebagai berikut:

1. peserta didik difasilitasi untuk mencari tahu;

2. peserta didik belajar dari berbagai sumber belajar;

3. proses pembelajaran menggunakan pendekatan ilmiah;

4. pembelajaran berbasis kompetensi;

5. pembelajaran terpadu;

6. pembelajaran yang menekankan pada jawaban divergen yang memiliki kebenaran multi dimensi;

7. pembelajaran berbasis keterampilan aplikatif;

8. peningkatan keseimbangan, kesinambungan, dan keterkaitan antara hard-skills dan soft-skills;

9. pembelajaran yang mengutamakan pembudayaan dan pemberdayaan peserta didik sebagai pembelajar sepanjang hayat;

10. pembelajaran yang menerapkan nilai-nilai dengan memberi keteladanan (ing ngarsa sung tuladha), membangun kemauan (ing madya mangun karsa), dan mengembangkan kreativitas peserta didik dalam proses pembelajaran (tut wuri handayani);

11. pembelajaran yang berlangsung di rumah, di sekolah, dan di masyarakat;

12. pemanfaatan teknologi informasi dan komunikasi untuk meningkatkan efisiensi dan efektivitas pembelajaran;

13. pengakuan atas perbedaan individual dan latar belakang budaya peserta didik; dan

14. suasana belajar menyenangkan dan menantang.

Berdasarkan masalah yang telah diuraikan pada bagian pendahuluan, maka pada kesempatan kali ini Penulis akan sedikit mengupas tentang bagaimana cara agar para siswa dapat aktif bertanya dalam kelas matematika berdasarkan kurikulum 2013. Berikut ini penulis akan mengurai tentang cara agar hal tersebut dapat terwujud sesuai dengan yang diharapkan. Uraian berikut berdasarkan hasil pengalaman Penulis, hasil penelitian selama dua tahun terakhir ini, dan hasil kajian tentang Kurikulum 2013. Hasil temuan yang didapat oleh Penulis adalah ada enam point utama yang harus diketahui dan dipahami oleh guru dan ada sembilan point khusus yang harus dilakukan oleh guru dalam kegiatan bertanya. Berikut enam poin utama yang harus diketahui dan dipahami oleh para Guru.

\section{Enam Poin Utama yang Harus Diketahui dan Dipahami oleh Para Guru.}

Pertama, Guru harus paham tentang Kurikulum 2013. Kurikulum 2013 dikembangkan berdasarkan berbagai alasan (Kemendikbud, 2015). Alasan-alasan tersebut antara lain: (1) Tantangan Internal, (2) Tantangan Eksternal, (3) Penyempurnaan Pola Pikir, (4) Penguatan Tata Kelola Kurikulum, (5) Penguatan Materi, dan (6) Karakteristik Kurikulum 2013. Berikut uraiannya:

\section{Tantangan Internal}

Tantangan internal antara lain terkait dengan kondisi pendidikan dikaitkan dengan tuntutan pendidikan yang mengacu kepada 8 (delapan) Standar Nasional Pendidikan yang meliputi standar isi, standar proses, standar kompetensi lulusan, standar pendidik dan tenaga kependidikan, standar sarana dan prasarana, standar pengelolaan, standar pembiayaan, dan standar penilaian pendidikan. 
Tantangan internal lainnya terkait dengan perkembangan penduduk Indonesia dilihat dari pertumbuhan penduduk usia produktif. Saat ini jumlah penduduk Indonesia usia produktif (15-64 tahun) lebih banyak dari usia tidak produktif (anak-anak berusia 0-14 tahun dan orang tua berusia 65 tahun ke atas). Jumlah penduduk usia produktif ini akan mencapai puncaknya pada tahun 2020-2035 pada saat angkanya mencapai $70 \%$. Oleh sebab itu tantangan besar yang dihadapi adalah bagaimana mengupayakan agar sumberdaya manusia usia produktif yang melimpah ini dapat ditransformasikan menjadi sumberdaya manusia yang memiliki kompetensi dan keterampilan melalui pendidikan agar tidak menjadi beban.

\section{Tantangan Eksternal}

Tantangan eksternal antara lain terkait dengan arus globalisasi dan berbagai isu yang terkait dengan masalah lingkungan hidup, kemajuan teknologi dan informasi, kebangkitan industri kreatif dan budaya, dan perkembangan pendidikan di tingkat internasional. Arus globalisasi akan menggeser pola hidup masyarakat dari agraris dan perniagaan tradisional menjadi masyarakat industri dan perdagangan modern seperti dapat terlihat di World Trade Organization (WTO), Association of Southeast Asian Nations (ASEAN) Community, Asia-Pacific Economic Cooperation (APEC), dan ASEAN Free Trade Area (AFTA). Tantangan eksternal juga terkait dengan pergeseran kekuatan ekonomi dunia, pengaruh dan imbas teknosains serta mutu, investasi, dan transformasi bidang pendidikan. Keikutsertaan Indonesia di dalam studi International Trends in International Mathematics and Science Study (TIMSS) dan Program for International Student Assessment (PISA) sejak tahun1999 juga menunjukkan bahwa capaian anak-anak Indonesia tidak menggembirakan dalam beberapa kali laporan yang dikeluarkan TIMSS dan PISA. Hal ini disebabkan antara lain banyaknya materi uji yang ditanyakan di TIMSS dan PISA tidak terdapat dalam kurikulum Indonesia.

\section{Penyempurnaan Pola Pikir}

Kurikulum 2013 dikembangkan dengan penyempurnaan pola pikir sebagai berikut:

a. Penguatan pola pembelajaran yang berpusat pada siswa. Siswa harus memiliki pilihan-pilihan terhadap materi yang dipelajari dan gaya belajarnya (learning style) untuk memiliki kompetensi yang sama ;

b. Penguatan pola pembelajaran interaktif (interaktif guru-siswa-masyarakat-lingkungan alam, sumber/media lainnya);

c. Penguatan pola pembelajaran secara jejaring (siswa dapat menimba ilmu dari siapa saja dan dari mana saja yang dapat dihubungi serta diperoleh melalui internet);

d. Penguatan pembelajaran aktif-mencari (pembelajaran siswa aktif mencari semakin diperkuat dengan pendekatan pembelajaran saintifik);

e. Penguatan pola belajar sendiri dan kelompok (berbasis tim);

f. Penguatan pembelajaran berbasis multimedia;

g. Penguatan pola pembelajaran berbasis klasikal-massal dengan tetap memperhatikan pengembangan potensi khusus yang dimiliki setiap siswa;

h. Penguatan pola pembelajaran ilmu pengetahuan jamak (multidisciplines); dan

i. Penguatan pola pembelajaran kritis.

4. Penguatan Tata Kelola Kurikulum

Kurikulum 2013 dilakukan penguatan tata kelola sebagai berikut.

a. Penguatan tata kerja guru lebih bersifat kolaboratif;

b. Penguatan manajeman sekolah melalui penguatan kemampuan manajemen kepala sekolah sebagai pimpinan kependidikan (educational leader); dan

c. Penguatan sarana dan prasarana untuk kepentingan manajemen dan proses pembelajaran.

5. Penguatan Materi

Penguatan materi dilakukan dengan cara pengurangan materi yang tidak relevan serta pendalaman dan perluasan materi yang relevan bagi siswa.

6. Karakteristik Kurikulum 2013

Kurikulum 2013 dirancang dengan karakteristik sebagai berikut. 
a. Mengembangkan keseimbangan antara sikap spiritual dan sosial, pengetahuan, dan keterampilan, serta menerapkannya dalam berbagai situasi di sekolah dan masyarakat;

b. Menempatkan sekolah sebagai bagian dari masyarakat yang memberikan pengalaman belajar agar sisw amampu menerapkan apa yang dipelajari di sekolah ke masyarakat dan memanfaatkan masyarakat sebagai sumber belajar;

c. Memberi waktu yang cukup leluasa untuk mengembangkan berbagai sikap, pengetahuan, dan keterampilan;

d. Mengembangkan kompetensi yang dinyatakan dalam bentuk Kompetensi Inti kelas yang dirinci lebih lanjut dalam kompetensi dasar mata pelajaran;

e. Mengembangkan Kompetensi Inti kelas menjadi unsur pengorganisasi (organizing elements) Kompetensi Dasar. Semua Kompetensi Dasar dan proses pembelajaran dikembangkan untuk mencapai kompetensi yang dinyatakan dalam Kompetensi Inti;

f. Mengembangkan Kompetensi Dasar berdasar pada prinsip akumulatif, saling memperkuat (reinforced) dan memperkaya (enriched) antar-mata pelajaran dan jenjang pendidikan (organisasi horizontal dan vertikal).

Kedua, Perubahan Mindset Guru. Beberapa perubahan mindset yang perlu dilakukan oleh Guru antara lain adalah:

1) Guru hanya sebagai fasilitator saja dalam kegiatan pembelajaran. Guru tidak lagi dianggap sebagai satusatunya sumber informasi dalam pembelajaran. Guru harus berubah menjadi hanya penyedia pengalaman belajar.

2) Guru tidak lagi harus menerangkan dan menjelaskan materi. Pembelajaran tidak lagi dipandang sebagai proses transfer ilmu pengetahuan kepada siswa. Pembelajaran lebih dipandang sebagai proses membantu siswa memaknai pengalaman interaksinya dengan sumber belajar.

3) Guru harus mengubah persepsinya bahwa belajar bisa berlangsung dimana saja, dan kapan saja. Guru harus memandang bahwa belajar di dalam kelas hanya sebagai salah satu saja dari sekian banyak macam kegiatan belajar lainnya.

4) Guru harus mengubah persepsinya bahwa pembelajaran bukan lagi untuk menumpuk-numpuk pengetahuan. Pembelajaran harus dipandang sebagai upaya untuk mengembangkan kemampuan berpikir siswa (kritis, kreatif, dan self regulatif).

5) Guru harus berubah dari pembelajaran yang menekankan kepada kecepatan dan ketepatan berhitung, menjadi pembelajaran yang mengembangkan kemampuan merumuskan masalah.

6) Guru harus berubah dari menekankan pembelajaran yang bersifat individualistis, menjadi pembelajaran yang mendukung tumbuh berkembangnya kemauan dan kemampuan bekerjasama.

7) Guru harus mengubah persepsinya bahwa pekerjaan mengajar itu tidak lagi dominasi dirinya, tetapi siapa saja bisa menjadi guru.

Ketiga, Guru paham tentang pendekatan saintifik dalam pembelajaran. Pendekatan pembelajaran yang disarankan dalam kurikulum 2013 adalah pendekatan saintifik yang dikenal dengan $5 M$ (Mengamati, Menanya, Menggali Informasi, Mengasosiasi, dan Mengkomunikasikan). Berikut beberapa hal yang perlu mendapatkan perhatian kita bersama.

\section{Mengamati}

Pengalaman belajar pada kegiatan pengamatan dapat dilakukan dengan cara membaca, mendengar, menyimak, melihat (tanpa atau dengan alat) objek-objek matematika tertentu terkait masalah atau topik kegiatan. Kegiatan pengamatan juga bisa dilakukan dengan memperhatikan sesuatu melalui indera secara cermat. Adapun yang perlu kita ketahui dalam kegiatan pengamatan adalah bahwa mengamati tidak hanya dilakukan dengan bantuan mata, tetapi juga bisa dengan indera yang lain. Kemudian hasil pengamatan dapat berupa definisi, aksioma, postulat, teorema, sifat, grafik dan lain sebagainya. Pengalaman belajar mengamati ini diharapkan dapat memfasilitasi siswa dalam mengembangkan dan melatih kesungguhan, ketelitian, dan kemampuan mencari informasi.

\section{Menanya}




\section{4 | Prosiding Seminar Nasional Matematika dan Pembelajarannya \\ Program Studi Pendidikan Matematika FKIP Universitas Jember, 23 Oktober 2016 \\ ISBN: 987-602-18397-4-4}

Setelah terjadi proses mengamati, pengalaman belajar peserta didik berikutnya yang difasilitasi guru adalah pengalaman belajar menanya. Pengalaman belajar tersebut dimaknai sebagai menanya dan mempertanyakan terhadap hal-hal yang diamati. Terjadinya kegiatan 'menanya' oleh siswa dapat disebabkan oleh karena belum dipahaminya hal-hal yang diamati, atau dapat pula karena ingin mendapatkan informasi tambahan tentang halhal yang diamati. Agar proses menanya oleh peserta didik semakin hari berjalan semakin lancar dan berkualitas, guru dapat memfasilitasi dengan pancingan pertanyaan-pertanyaan yang berfungsi menggiring peserta didik untuk mempertanyakan hal-hal yang diamati.

\section{Menggali Informasi/Sedikir Informasi}

Setelah terjadi proses menanya, pengalaman belajar siswa berikutnya adalah menggali informasi. Pada buku siswa disajikan dua jenis informasi, yaitu informasi langsung dan tidak langsung. Pertama, informasi disajikan secara langsung, sehingga menuntut siswa untuk cermat dalam memahami informasi yang disajikan. Kedua, informasi disajikan dengan mengajak siswa melakukan suatu aktivitas yang mengarah pada informasi yang ingin dicapai, untuk itu siswa harus aktif dalam mengikuti panduan buku siswa dan guru. Selain informasi yang diperoleh dari buku siswa, diharapkan siswa juga aktif membaca informasi sumber lain, mengamati objek/kejadian/aktivitas, atau melakukan wawancara dengan nara sumber. Dari Membelajarkan mengumpulkan informasi ini data-data yang selanjutnya siap diolah, dihubungkan antara data yang satu dengan yang lainnya (diasosiasikan), dianalisis, dan dinalar.

\section{Menalar/Mengasosisi}

Setelah mengalami proses mengamati, menanya, dan menggali informasi maka pengalaman belajar pokok berikutnya adalah mengolah informasi atau mengasosiasikan. Membelajarkan mengolah informasi dimaknai sebagai mengolah informasi yang sudah dikumpulkan baik terbatas dari hasil Membelajarkan mengumpulkan/eksperimen mau pun hasil dari Membelajarkan mengamati dan Membelajarkan mengumpulkan informasi. Sedangkan proses pengolahan informasi dapat terjadi dari yang bersifat menambah keluasan dan kedalaman sampai kepada yang bersifat mencari solusi dari berbagai sumber yang memiliki pendapat yang berbeda atau bahkan bertentangan. Pada buku siswa Membelajarkan menalar disajikan dalam bentuk pertanyaan-pertanyaan yang diharapkan akan terjawab oleh siswa setelah melalu Membelajarkan mengamati hingga menggali informasi. Hasil dari Membelajarkan menalar ini berupa jawaban, pernyataan, atau kesimpulan.

\section{Berbagi/Mengkomunikasikan}

Setelah mengalami proses mengamati, menanya, mengumpulkan, dan mengolah informasi maka pengalaman belajar pokok berikutnya adalah mengkomunikasikan yang dimaknai sebagai Membelajarkan menyampaikan hasil pengamatan, atau kesimpulan yang diperoleh berdasarkan hasil analisis secara tertulis, lisan, ataupun dengan media. Tujuan dari Membelajarkan berbagi adalah melatih siswa untuk berani menyampaikan ide kepada orang lain. Dengan adanya Membelajarkan berbagi, diharapkan akan tumbuh pada diri siswa sikap empati, saling menghargai, dan menghormati perbedaan orang lain.

Keempat, Guru mampu menggunakan atau membuat Kegiatan Pengamatan. Guru dapat menggunakan kegiatan pembelajaran yang telah ada pada buku paket atau Guru dapat membuat Kegiatan Pengamatan berdasarkan kondisi sekolahnya masing-masing. Mengamati pada dasarnya adalah kegiatan memperhatikan sesuatu, dengan menggunakan indera, secara cermat. Mengamati dapat dilakukan dengan cara membaca, mendengar, menyimak, melihat (tanpa atau dengan alat) objek-objek matematika tertentu terkait masalah atau topik kegiatan. Hasil pengamatan dapat berupa definisi, aksioma, postulat, teorema, sifat, grafik dan lain sebagainya. Pengalaman belajar mengamati ini diharapkan dapat memfasilitasi siswa dalam mengembangkan dan melatih kesungguhan, ketelitian, dan kemampuan mencari informasi.

Kelima, Guru harus mendorong siswa mau dan mampu bertanya, terutama mengajukan pertanyaan yang bersifat investigatif (pertanyaan yang mendorong orang yang ditanya untuk melakukan eksplorasi terlebih dahulu sebelum menjawabnya). Pada fase menanya ini, yang perlu membuat pertanyaan adalah siswa, bukan gurunya.

Keenam, Guru perlu memahami model-model pembelajaran yang dapat mendukung dalam penerapan pendekatan saintifik. Model pembelajaran yang mendukung penerapan pendekatan sintifik diantaranya adalah 
ISBN: 987-602-18397-4-4

model pembelajaran Berbasis Penemuan (Discovery Learning), Model Pembelajaran Berbasis Masalah (Problem Based Learning), dan Model Pembelajaran Berbasis Projek (Project Based Learning).

\section{Sembilan Point Khusus yang Harus Dilakukan oleh Para Guru}

Adapun sembilan point khusus yang harus dilakukan oleh guru agar para siswa aktif bertanya dalam legiatan pembelajaran adalah sebagai berikut:

1) Mengenalkan suatu fenomena menarik yang belum pernah dikenali oleh siswa sebelumnya. Seperti yang telah diuraikan pada point keempat, bahwa Guru mampu membuat Kegiatan Pengamatan. Artinya adalah siswa akan mengajukan pertanyaan jikalau yang diamati itu benar-benar manarik dan membuat siswa penasaran terhadap apa yang diamati. Perhatikan gambar berikut.
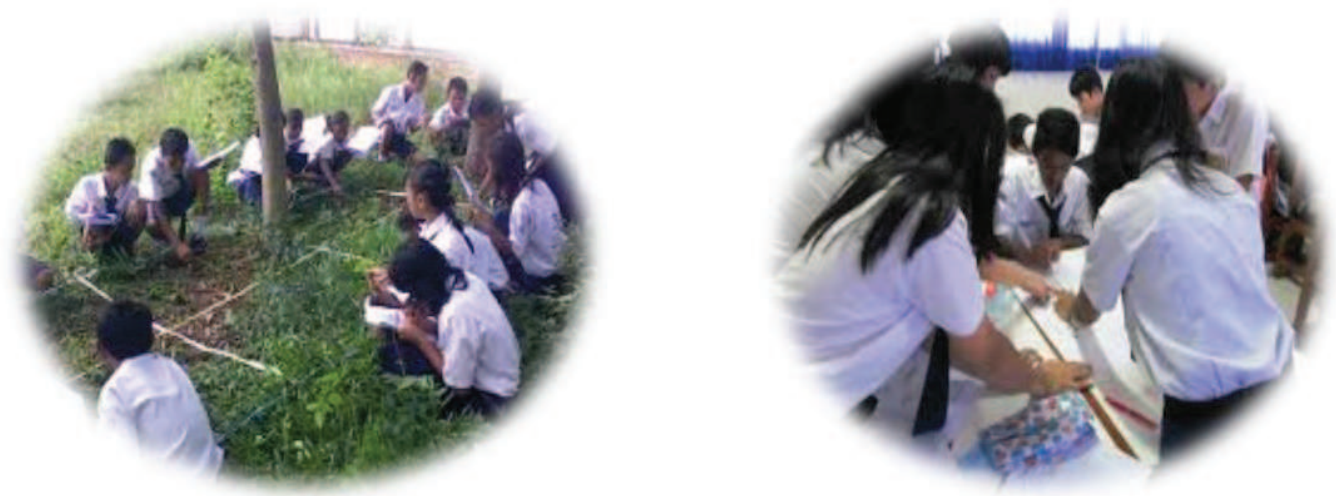

Gambar 2 kegiatan siswa dalam pembelajaran

\section{Contoh 1:}

Sebagai contoh pada bidang studi Matematika SMP Kelas 8, terlebih dulu diberikan pengantar awal tentang relasi dan fungsi

Dapatkah kalian memahami pesan berikut:

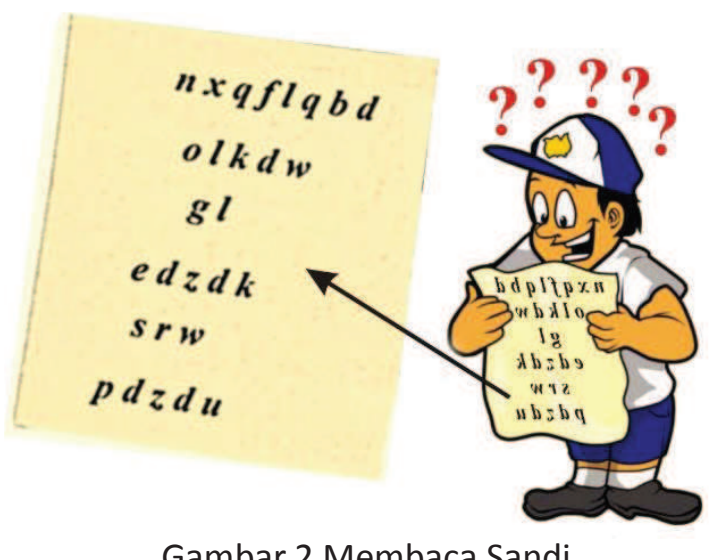

Gamhar 7 Memhara Sandi

Tanpa mengetahui kode sandinya, pesan di atas tentu tidak bisa dimengerti. Lain halnya jika kita punya kode pesan sebagai berikut.

\begin{tabular}{|l|l|l|l|l|l|l|l|l|l|l|l|l|l|l|l|l|l|l|l|l|l|l|l|l|l|}
\hline $\mathbf{A}$ & $\mathbf{B}$ & $\mathbf{C}$ & $\mathbf{D}$ & $\mathbf{E}$ & $\mathbf{F}$ & $\mathbf{G}$ & $\mathbf{H}$ & $\mathbf{I}$ & $\mathbf{J}$ & $\mathbf{K}$ & $\mathbf{L}$ & $\mathbf{M}$ & $\mathbf{N}$ & $\mathbf{O}$ & $\mathbf{P}$ & $\mathbf{Q}$ & $\mathbf{R}$ & $\mathbf{S}$ & $\mathbf{T}$ & $\mathbf{U}$ & $\mathbf{V}$ & $\mathbf{W}$ & $\mathbf{X}$ & $\mathbf{Y}$ & $\mathbf{Z}$ \\
\hline $\boldsymbol{d}$ & $\boldsymbol{e}$ & $\boldsymbol{f}$ & $\boldsymbol{g}$ & $\boldsymbol{h}$ & $\boldsymbol{I}$ & $j$ & $\boldsymbol{j}$ & $\boldsymbol{l}$ & $\boldsymbol{m}$ & $\boldsymbol{n}$ & $\boldsymbol{O}$ & $\boldsymbol{p}$ & $\boldsymbol{q}$ & $\boldsymbol{r}$ & $\boldsymbol{s}$ & $\boldsymbol{t}$ & $\boldsymbol{u}$ & $\boldsymbol{v}$ & $\boldsymbol{w}$ & $\boldsymbol{x}$ & $\boldsymbol{y}$ & $\boldsymbol{z}$ & $\boldsymbol{a}$ & $\boldsymbol{b}$ & $\boldsymbol{c}$ \\
\hline
\end{tabular}

Artinya huruf A di tulis sebagai $d$, huruf B ditulis sebagai $e$, huruf $\mathrm{C}$ ditulis sebagai $f$ dll, maka sandi-sandi di atas artinya adalah: 


\section{Kuncinya lihat di bawah pot mawar}

Sekarang pesan itu memiliki makna yang jelas.

Dalam kehidupan sehari-hari, seseorang kadangkala merahasiakan pesan yang ingin disampaikan. Dia tidak ingin pesannya dengan mudah bisa dibaca oleh orang lain, apalagi oleh orang yang tidak diinginkan.

Untuk mengetahui lebih dalam tentang karekterikstik fungsi dan memahami tentang ciri-ciri fungsi, lakukan kegiatan berikut.

\section{Memahami Ciri-Ciri Fungsi}

Fungsi merupakan salah satu konsep penting dalam matematika. Dengan mengenali fungsi atau hubungan fungsional antar unsur-unsur matematika, kita bisa lebih mudah memahami suatu permasalahan, dan menyelesaikannya. Karena itu, memahami fungsi merupakan hal yang sangat diharapkan dalam belajar matematika.

Pertama kali, mari kita pelajari ciri-ciri dari suatu fungsi.

Perhatikan aturan membuat sandi sebagai berikut:

Aturan 1:

\begin{tabular}{|l|l|l|l|l|l|l|l|l|l|l|l|l|l|l|l|l|l|l|l|l|l|l|l|l|l|}
\hline $\mathbf{A}$ & $\mathbf{B}$ & $\mathbf{C}$ & $\mathbf{D}$ & $\mathbf{E}$ & $\mathbf{F}$ & $\mathbf{G}$ & $\mathbf{H}$ & $\mathbf{I}$ & $\mathbf{J}$ & $\mathbf{K}$ & $\mathbf{L}$ & $\mathbf{M}$ & $\mathbf{N}$ & $\mathbf{O}$ & $\mathbf{P}$ & $\mathbf{Q}$ & $\mathbf{R}$ & $\mathbf{S}$ & $\mathbf{T}$ & $\mathbf{U}$ & $\mathbf{V}$ & $\mathbf{W}$ & $\mathbf{X}$ & $\mathbf{Y}$ & $\mathbf{Z}$ \\
\hline $\boldsymbol{d}$ & $\boldsymbol{e}$ & $\boldsymbol{f}$ & $\boldsymbol{G}$ & $\boldsymbol{h}$ & $\boldsymbol{i}$ & $\boldsymbol{j}$ & $\boldsymbol{k}$ & $\boldsymbol{l}$ & $\boldsymbol{m}$ & $\boldsymbol{n}$ & $\boldsymbol{O}$ & $\boldsymbol{p}$ & $\boldsymbol{q}$ & $\boldsymbol{r}$ & $\boldsymbol{s}$ & $\boldsymbol{t}$ & $\boldsymbol{u}$ & $\boldsymbol{v}$ & $\boldsymbol{w}$ & $\boldsymbol{x}$ & $\boldsymbol{y}$ & $\boldsymbol{z}$ & $\boldsymbol{a}$ & $\boldsymbol{b}$ & $\boldsymbol{c}$ \\
\hline
\end{tabular}

Aturan 2:

\begin{tabular}{|l|l|l|l|l|l|l|l|l|l|l|l|l|l|l|l|l|l|l|l|l|l|l|l|l|l|}
\hline $\mathbf{A}$ & $\mathbf{B}$ & $\mathbf{C}$ & $\mathbf{D}$ & $\mathbf{E}$ & $\mathbf{F}$ & $\mathbf{G}$ & $\mathbf{H}$ & $\mathbf{I}$ & $\mathbf{J}$ & $\mathbf{K}$ & $\mathbf{L}$ & $\mathbf{M}$ & $\mathbf{N}$ & $\mathbf{O}$ & $\mathbf{P}$ & $\mathbf{Q}$ & $\mathbf{R}$ & $\mathbf{S}$ & $\mathbf{T}$ & $\mathbf{U}$ & $\mathbf{V}$ & $\mathbf{W}$ & $\mathbf{X}$ & $\mathbf{Y}$ & $\mathbf{Z}$ \\
\hline $\boldsymbol{a}$ & $\boldsymbol{b}$ & $\boldsymbol{c}$ & $\mathbf{D}$ & $\boldsymbol{e}$ & $\boldsymbol{a}$ & $\boldsymbol{b}$ & $\boldsymbol{c}$ & $\boldsymbol{d}$ & $\boldsymbol{e}$ & $\boldsymbol{a}$ & $\mathbf{B}$ & $\boldsymbol{c}$ & $\boldsymbol{d}$ & $\boldsymbol{e}$ & $\boldsymbol{a}$ & $\boldsymbol{b}$ & $\boldsymbol{c}$ & $\boldsymbol{d}$ & $\boldsymbol{e}$ & $\boldsymbol{a}$ & $\boldsymbol{b}$ & $\boldsymbol{c}$ & $\boldsymbol{d}$ & $\boldsymbol{e}$ & $\boldsymbol{a}$ \\
\hline
\end{tabular}

Aturan 3:

\begin{tabular}{|l|l|l|l|l|l|l|l|l|l|l|l|l|l|l|l|l|l|l|l|l|l|l|l|l|l|}
\hline $\mathbf{A}$ & $\mathbf{B}$ & $\mathbf{C}$ & $\mathbf{D}$ & $\mathbf{E}$ & $\mathbf{F}$ & $\mathbf{G}$ & $\mathbf{H}$ & $\mathbf{I}$ & $\mathbf{J}$ & $\mathbf{K}$ & $\mathbf{L}$ & $\mathbf{M}$ & $\mathbf{N}$ & $\mathbf{O}$ & $\mathbf{P}$ & $\mathbf{Q}$ & $\mathbf{R}$ & $\mathbf{S}$ & $\mathbf{T}$ & $\mathbf{U}$ & $\mathbf{V}$ & $\mathbf{W}$ & $\mathbf{X}$ & $\mathbf{Y}$ & $\mathbf{Z}$ \\
\hline $\mathbf{1}$ & $\mathbf{2}$ & $\mathbf{3}$ & $\mathbf{4}$ & $\mathbf{5}$ & $\mathbf{6}$ & $\mathbf{7}$ & $\mathbf{8}$ & $\mathbf{9}$ & $\mathbf{0}$ & $\mathbf{1}$ & $\mathbf{2}$ & $\mathbf{3}$ & $\mathbf{4}$ & $\mathbf{5}$ & $\mathbf{6}$ & $\mathbf{7}$ & $\mathbf{8}$ & $\mathbf{9}$ & $\mathbf{0}$ & $\mathbf{1}$ & $\mathbf{2}$ & $\mathbf{3}$ & $\mathbf{4}$ & $\mathbf{5}$ & $\mathbf{6}$ \\
\hline
\end{tabular}

Aturan 4:

\begin{tabular}{|l|l|l|l|l|l|l|l|l|l|l|l|l|l|l|l|l|l|l|l|l|l|l|l|l|l|}
\hline $\mathbf{A}$ & $\mathbf{B}$ & $\mathbf{C}$ & $\mathbf{D}$ & $\mathbf{E}$ & $\mathbf{F}$ & $\mathbf{G}$ & $\mathbf{H}$ & $\mathbf{I}$ & $\mathbf{J}$ & $\mathbf{K}$ & $\mathbf{L}$ & $\mathbf{M}$ & $\mathbf{N}$ & $\mathbf{O}$ & $\mathbf{P}$ & $\mathbf{Q}$ & $\mathbf{R}$ & $\mathbf{S}$ & $\mathbf{T}$ & $\mathbf{U}$ & $\mathbf{V}$ & $\mathbf{W}$ & $\mathbf{X}$ & $\mathbf{Y}$ & $\mathbf{Z}$ \\
\hline $\boldsymbol{z}$ & $\boldsymbol{y}$ & $\boldsymbol{x}$ & $\boldsymbol{w}$ & $\boldsymbol{v}$ & $\boldsymbol{u}$ & $\boldsymbol{t}$ & $\boldsymbol{s}$ & $\boldsymbol{r}$ & $\boldsymbol{q}$ & $\boldsymbol{p}$ & $\boldsymbol{O}$ & $\boldsymbol{n}$ & $\boldsymbol{m}$ & $\boldsymbol{l}$ & $\boldsymbol{k}$ & $\boldsymbol{j}$ & $\boldsymbol{i}$ & $\boldsymbol{h}$ & $\boldsymbol{g}$ & $\boldsymbol{f}$ & $\boldsymbol{e}$ & $\boldsymbol{d}$ & $\boldsymbol{c}$ & $\boldsymbol{b}$ & $\boldsymbol{a}$ \\
\hline
\end{tabular}

Perhatikan pula kata-kata berikut.

1. Selidiki

2. Siapa

3. Sebenarnya

4. Si Udin

Dengan menggunakan aturan-aturan di atas, setiap kata tersebut akan berubah menjadi sandi. Supaya kalian tidak hanya membayangkan, coba lengkapi tabel berikut (boleh di kertas kerja terpisah), dan coba amati sandi yang mungkin dihasilkan.

Tabel 1 Daftar Kata Sandi

\begin{tabular}{|l|c|c|l|c|}
\hline \multirow{2}{*}{ Kata Asli } & \multicolumn{4}{|l|}{ Daftar Semua Kata Sandi yang Mungkin Dihasilkan Bila Menggunakan } \\
\cline { 2 - 5 } & Aturan 1 & Aturan 2 & Aturan 3 & Aturan 4 \\
\hline Selidiki & & & & \\
\hline Siapa & & & & \\
\hline Sebenarnya & & & & \\
\hline
\end{tabular}


Perhatikan dengan seksama apakah kata sandi setiap kata bersifat tunggal! Maksudnya: “Apakah setiap kata disandikan hanya dengan satu 'sandi' saja?

Kalau kalian mengerjakan dengan sungguh-sungguh, beberapa sandi yang mungkin dihasilkan dapat dilihat pada tabel berikut.

\begin{tabular}{|l|c|c|c|c|}
\hline \multirow{2}{*}{ Kata Asli } & \multicolumn{4}{|l|}{ Daftar Semua Kata Sandi yang Mungkin Dihasilkan Bila Menggunakan } \\
\cline { 2 - 5 } & Aturan 1 & Aturan 2 & Aturan 3 & Aturan 4 \\
\hline Selidiki & vholglnl & & & \\
\hline Siapa & & Ddaaa & & hvyvmzimbz \\
\hline Sebenarnya & & & & \\
\hline Si Udin & & & 991494 & \\
\hline
\end{tabular}

Coba lengkapi tabel di atas.

Sebagai orang yang kritis dan kreatif, kita ias mengajukan beberapa pertanyaan. Sebagai contoh:

1. Manakah dari aturan 1 sampai degan aturan 4 tersebut yang paling baik digunakan untuk membuat kata sandi? Mengapa?

2. Dengan aturan 2, kata "SIAPA" disandikan menjadi "ddaaa". Apa keunggulan dan kekurangan dari aturan penyandian ini?

Coba kalian rumuskan sedikitnya 3 pertanyaan lain terkait dengan aturan penyandian di atas. Kalau bisa, upayakan pertanyaan kalian memuat kata-kata "sandi" dan "pilihanmu".

\section{Contoh 2:}

Sebagai contoh pada bidang studi Matematika SMP Kelas 8, terlebih dulu diberikan pengantar awal tentang Korespondensi satu-satu.

Setelah kalian melakukan tentang relasi dan fugsi. Kemudian kita akan melakukan kegiatan terakhir dari materi bab ini, yaitu tentang korespondensi satu-satu. Untuk lebih jelasnya ikutilah kegiatan berikut ini.

\section{Masalah 1.}

Agar kalian memahami pengertian tentang korespondensi satu satu, perhatikan Gambar 3 di samping. Perhatikan deretan rumah di suatu daerah. Setiap rumah memiliki nomor rumah tertentu yang berbeda dengan nomor rumah yang lain. Mungkinkah satu rumah memiliki dua nomor rumah? Atau mungkinkah dua rumah memiliki nomor rumah yang sama? Tentu saja jawabannya tidak. Hubungan antara rumah dan nomor rumah merupakan suatu fungsi yang disebut korespondensi satu-satu.

\section{Masalah 2}

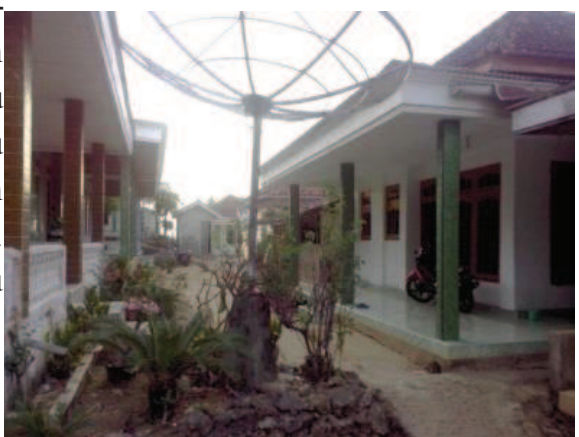

Gambar 3. Deretan rumah

Kasus lain yang menggambarkan korespondensi satu-satu sebagai berikut. Lima orang siswa dengan nomor induk sekolah di SMP Ruhas Malang, adalah sebagai berikut.

As'ari memiliki nomor induk 219, 
ISBN: 987-602-18397-4-4

Tohir memiliki nomor induk 279,

Taufiq memiliki nomor induk 292,

Erik memiliki nomor induk 258,

Zainul memiliki nomor induk 224,

Jika dimisalkan A himpunan siswa, maka $\mathrm{A}=\{$ As'ari, Tohir, Taufiq, Erik, Zainul $\}$ dan $\mathrm{B}$ adalah himpunan angka $=\{219,224,258,279,292\}$ maka relasi dari A ke B adalah "nomor induk" dan relasi dari B ke A adalah "Nama pemilik nomor induk". Bagaimana bentuk diagram panah dari kedua relasi tersebut?

Kedua Masalah tersebut merupakan contoh dari kehidupan nyata yang berkaitan dengan materi korespondensi satu-satu. Sebelum menyelesaikan masalah tersebut, sebaiknya terlebih dulu kita lakukan kegiatan berikut ini.

Ayo Kita Amati

Pada tabel 3. ditunjukkan relasi dari anggota himpunan A ke anggota Himpunan B. Coba amatilah dengan cermat bentuk diagram panah pada tabel 3 berikut.

Tabel 2. Memahami korespondensi satu-satu

No. Contoh Korespondensi Satu-satu




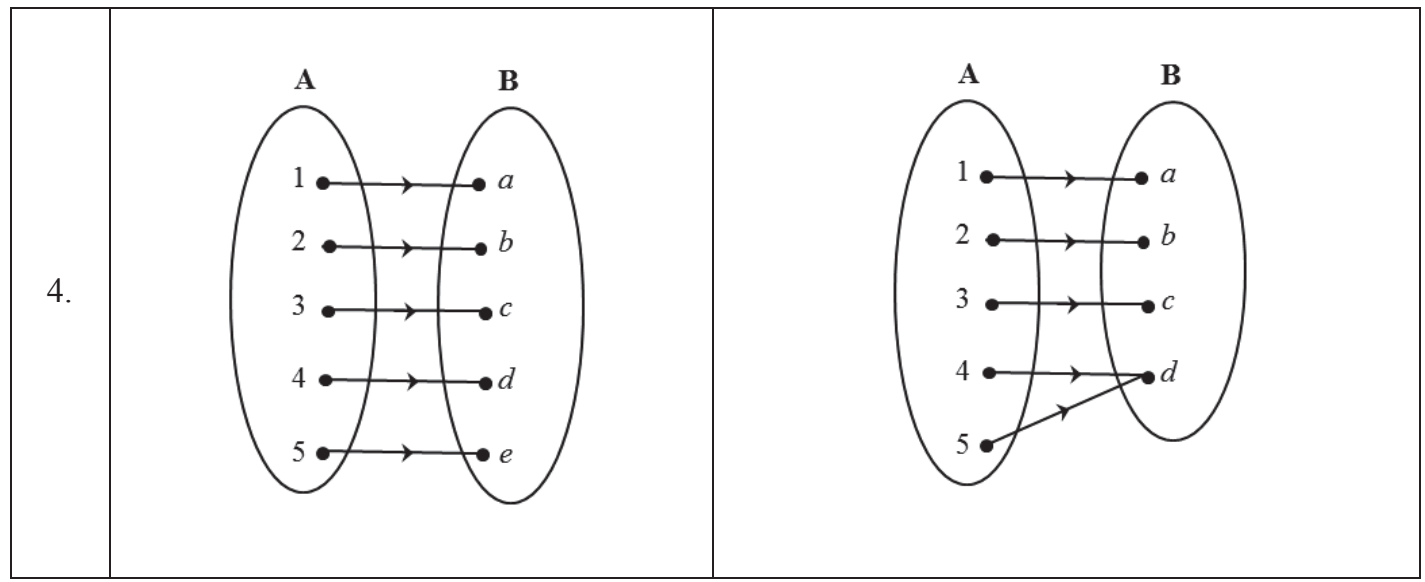

Pada kegiatan pengamatan ini: ajaklah siswa untuk mengamati tabel 3 di atas. Fokus pengamatannya adalah memperhatikan kedua diagram panah dengan anak panahnya, mengapa dikatakan korespondensi satu-satu dan mengapa bukan kurespondensi satu-satu. Kemudian ajaklah siswa untuk meperkirakan alasannya. Berilah motivasi kepada mereka untuk mendiskusikan tentang hubungan antara anggota himpunan A dengan himpunan anggota B, mengapa dikatakan korespondensi satu-satu dan mengapa bukan kurespondensi satu-satu.

\section{Contoh 3:}

Sebagai contoh pada bidang studi Matematika SMP Kelas 7, misalkan kita mengenalkan istilah "sisi panjang", "sisi pendek", "Pixel", "Luxam" yang belumpernah dikenal oleh siswa dan memang tidak ada artinya sama sekali. Istilah-istilah ini kita kenalkan dengan meminta siswa mengamati hal berikut:

\section{Ayo Kita Amati}

Tabel 4. Persegi dan Persegipanjang

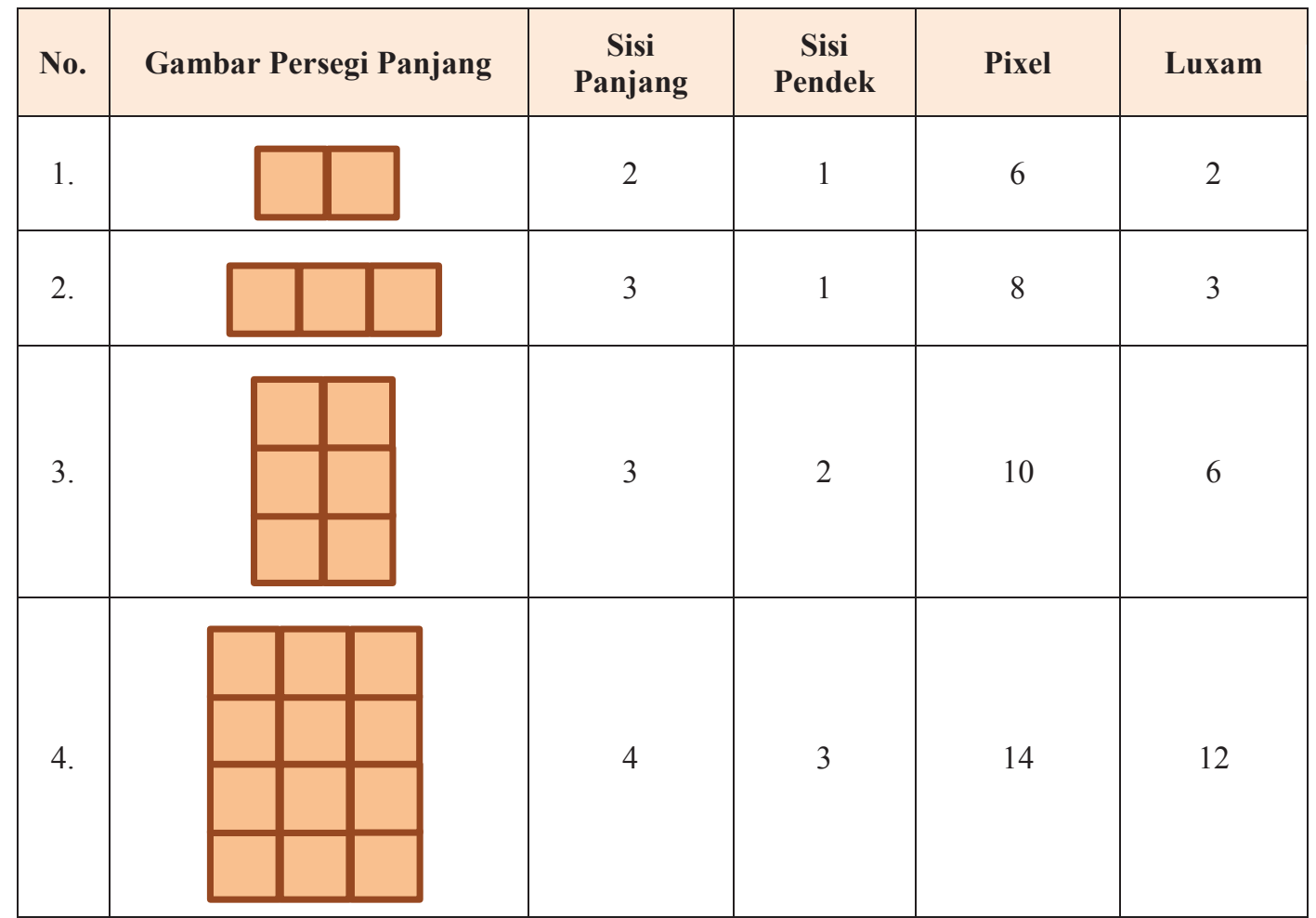




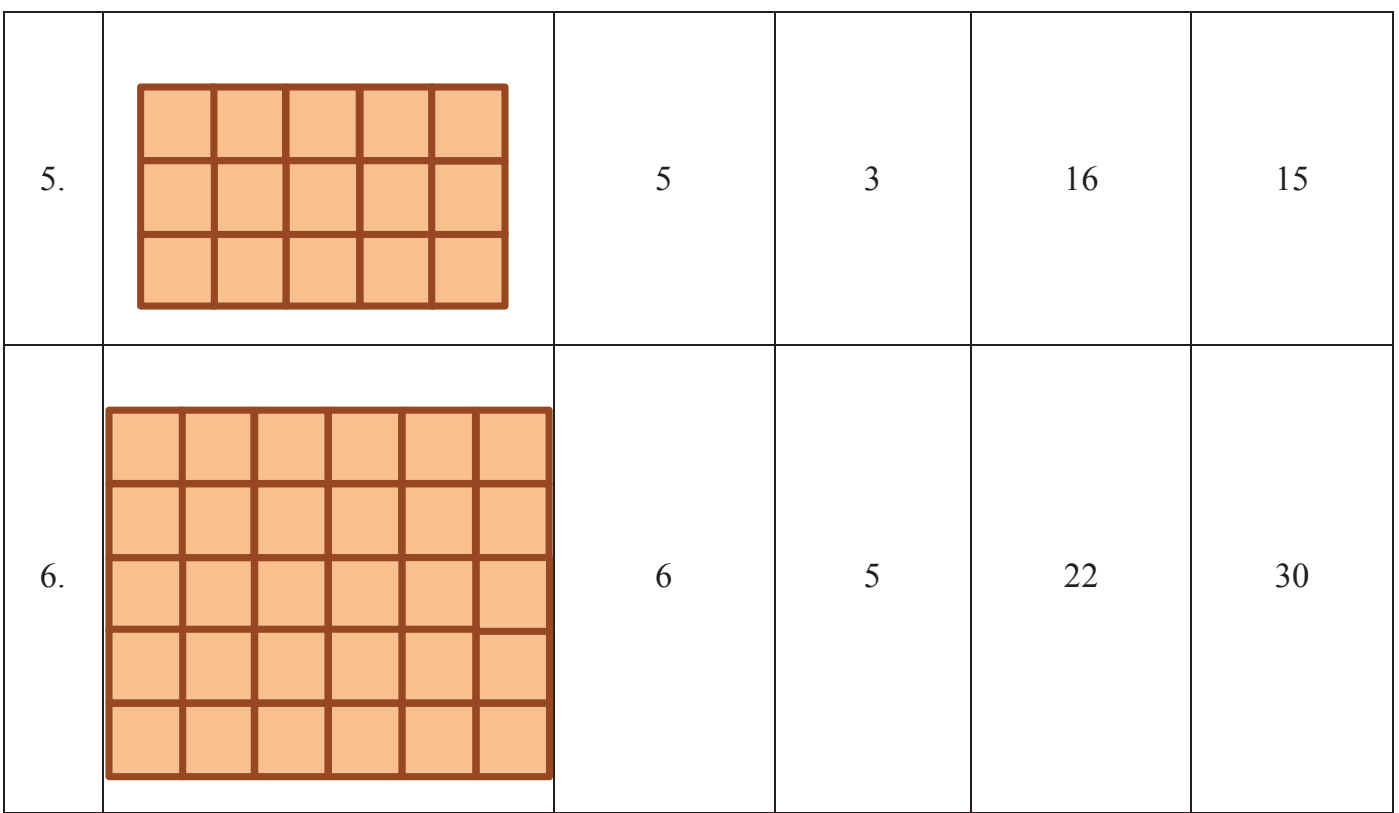

Sebenarnya kalau kita perhatikan dengan cermat, istilah "Pixel" dan "Luxam" itu sebenarnya sama saja artinya dengan keliling dan luas daerah persegi panjang. Akan tetapi jika kita menggunakan istilah yang sebenarnya, yaitu keliling dan luas daerah persegi panjang, kemungkinannya siswa akan cenderung mengandalkan kepada ingatan dan tidak mengajukan pertanyaan. Kalau itu yang terjadi, maka gagallah rencana kita untuk mendorong siswa menanya.

2) Words in a question. Siswa diberi beberapa kata atau rangkaian kata, dan mereka diminta untuk membuat kalimat yang memuat kata-kata tersebut. Misalnya pada kegiatan pengamatan yang terdapat pada contoh 3 di atas, yaitu buatlah pertanyaan yang memuat kata-kata "sisi panjang" dan "sisi pendek". Buatlah pertanyaan yang memuat kata-kata "Pixel" atau "Luxam". Perhatikan contoh kagiatan siswa dalam point dua ini.

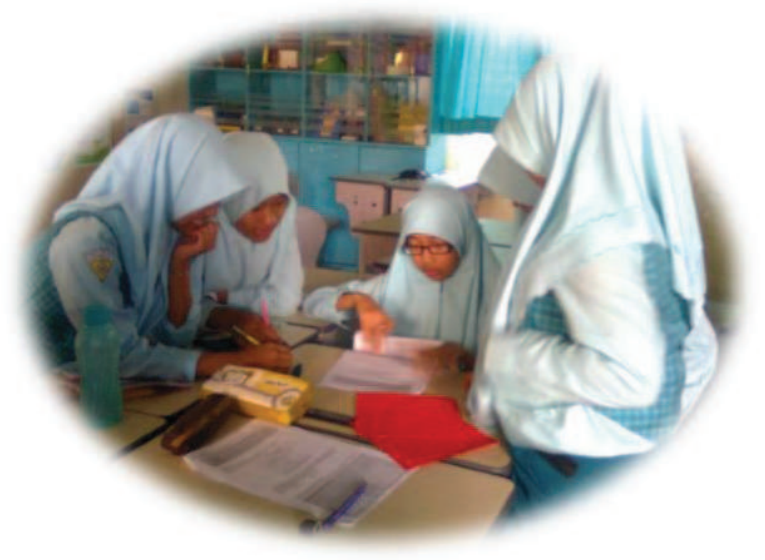

Gambar 3 Kegiatan siswa dalam merangkai kata

Dalam Kegiatan ini, ajaklah siswa untuk memperhatikan kotak persegi dan banyaknya kotak persegi disetiap bagian gambar, mulai gambar 1 sampai gambar 6. Berilah kesempatan kepada siswa untuk mengamati hubungan antara sisi panjang dan sisi lebar dengan keliling kotak persegi. Kemudian berilah kesempatan juga kepada siswa untuk mengamati hubungan antara sisi panjang dan sisi lebar dengan banyak kotak persegi. Perhatikan semua siswa yang sedang melakukan kegiatan pengamatan. Jika ada siswa yang memerlukan bantuan atau mengalami kesulitan untuk mengamati pada tabel tersebut, bantulah dengan memperhatikan keselutan yang dialami oleh siswa tersebut.

3) Guru memberikan contoh pertanyaan pancingan, misalkan apa yang harus diperhatikan pada sisi pendek dan sisi panjang? Bagaimana cara menemukan rumus Pixel dan rumus Luxam?. 
ISBN: 987-602-18397-4-4

Contoh pertanyaan:

1. Bagaimana cara mengetahui panjang Pixel persegi dan persegi panjang pada tabel 4 ?

2. Bagaimana cara mengetahui besar Luxam persegi dan persegi panjang pada tabel 4 ?

Pertanyaan yang dibuat oleh siswa salah satunya harus sesuai dengan petunjuk kata-kata yang sudah ditentukan, sedangkan pertanyaan berikutnya diperbolehkan dengan kata-katanya sendiri. Secara bergiliran siswa membacakan pertanyaan yang telah dibuat. Guru menilai pertanyaan dibuat oleh siswa.

Contoh kreteria penilaian kualitas pertanyaan; A: sangat baik, B: baik, C: cukup, dan D: kurang.

4) Guru membentuk kelompok belajar dalam kegiatan pengamatan dan bertanya. Setelah waktu pengamatan selesai, setiap siswa dalam satu kelompok wajib membuat minimal satu pertanyaan. Kemudian dipilih tiga pertanyaan yang paling bagus menurut kelompoknya. Setelah itu, tukarkan tiga pertanyaan tersebut dengan kelompok lain. Kemudian jawablah dan diskusikan tiga pertanyaan dari kelompok lain tersebut dalam kelompok masing-masing.

Contoh Hasil Kegiatan Bertanya
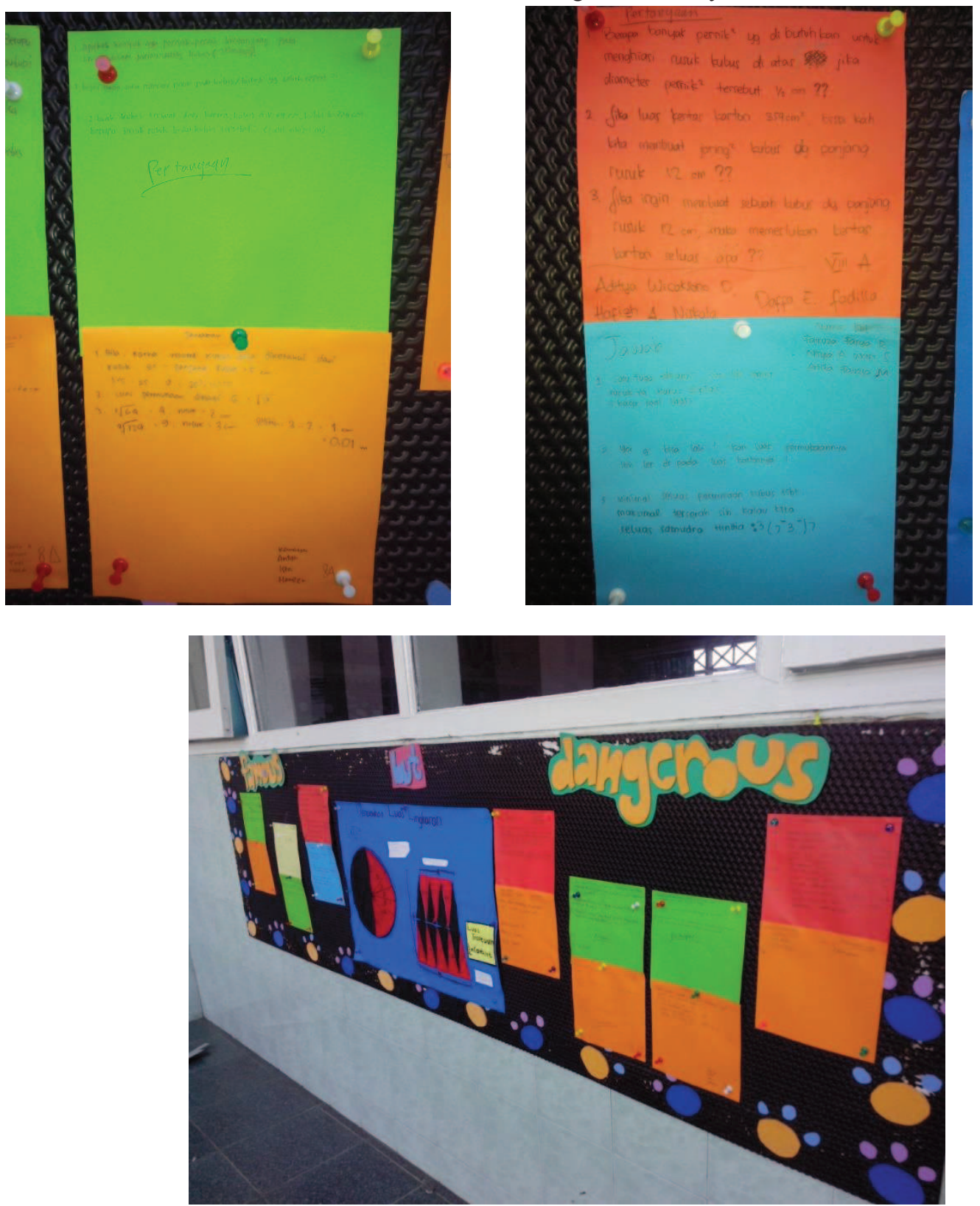

Gambar 4 Hasil Kegiatan Bertanya pada point 4 


\section{ISBN: 987-602-18397-4-4}

5) Guru dapat juga meminta siswa untuk bekerja dalam kelompok untuk membuat beberapa pertanyaan terlebih dahulu, dan selanjutnya meminta mereka bersepakat untuk memilih satu pertanyaan tertentu yang layak ditindak lanjuti dengan penyelidikan, baik oleh kelompok lain atau kelompok itu sendiri. Perhatikan contoh kagiatan siswa dalam point lima ini.
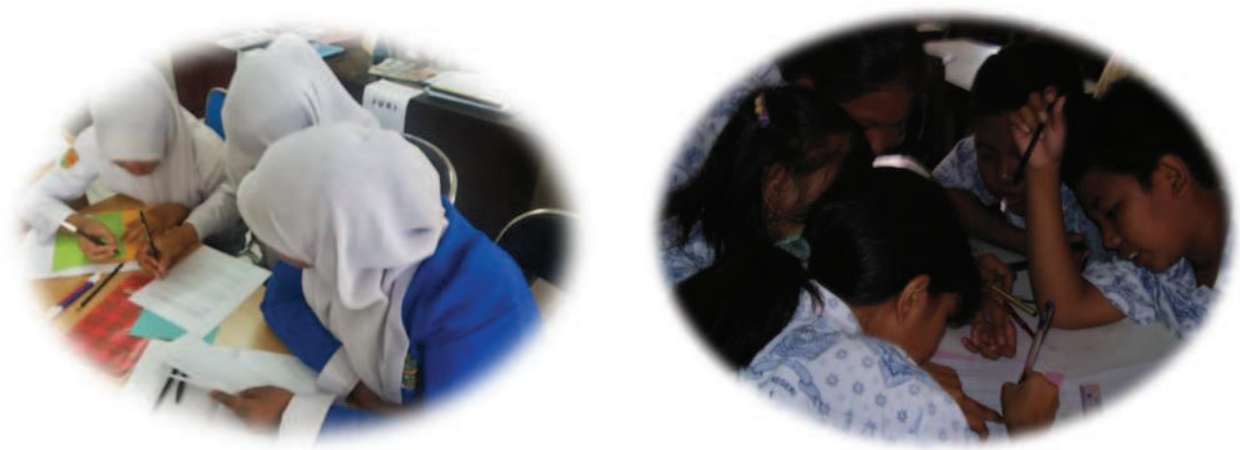

Gambar 4 Kegiatan bertanya siswa pada point 5

6) Guru memberikan kesempatan kepada setiap siswa untuk melakukan kegiatan pengamatan. Kemudian setiap siswa wajib membuat minimal tiga pertanyaan. Dalam fase ini guru mendatangi setiap siswa yang kelihatannya kesulitan untuk membuat pertanyaan, kemudian Guru mengarahkan siswa tersebut untuk mengamati kembali pada bahan kegiatan pengamatan. Sesekali Guru berperan "pura-pura" tidak tau sehingga menanyakan sesuatu kepada siswa tersebut, "kenapa kok bisa begini ya?", "bagaimana kalau menurut kalian" dan sebagainya.

7) Completing What if or What if not questions. Siswa diberi tugas untuk melengkapi pertanyaan yang dimulai dengan kata-kata What if yang berarti "Bagaimana kalau" atau kata What if not yang berarti "bagaimana kalau tidak".

8) Questioning Breakfast. Sarapan pagi "menanya". Setiap pagi, sebelum dimulai pelajaran, siswa diminta untuk menuliskan pertanyaan. Guru bisa mengondisikan agar pertanyaan yang dibuat siswa sesuai dengan tema dan KD yang sedang dibahas. Perhatikan contoh kagiatan siswa dalam point delapan ini.

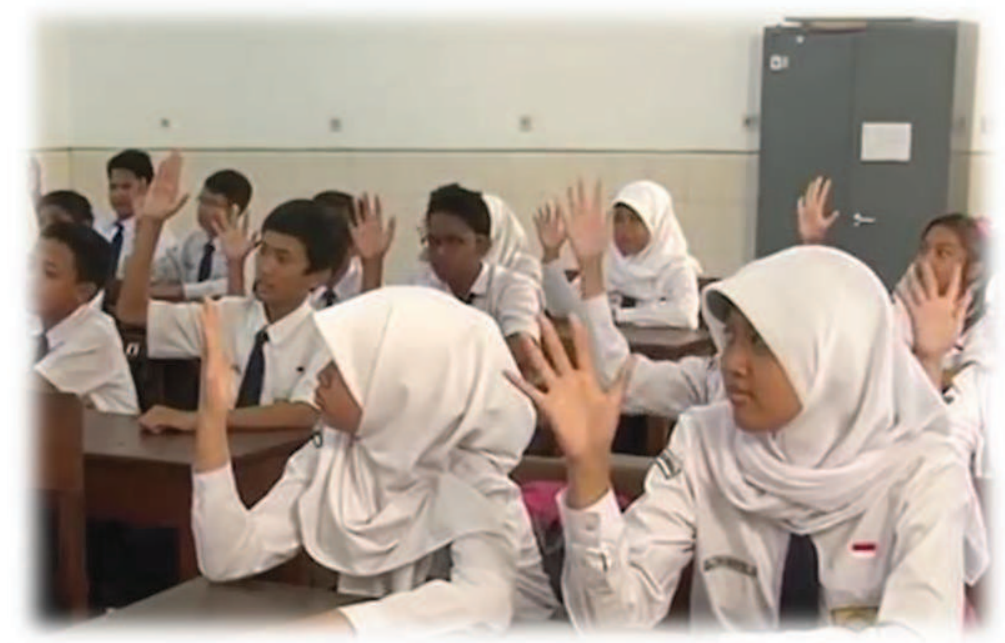

Gambar 4 Kegiatan bertanya siswa pada point 8

9) Questioning Appraisal. Pemberian penghargaan kepada siswa yang memiliki kuantitas dan kualitas pertanyaan investigatif yang baik. Dengan begitu, siswa mempersepsi kegiatan menanya sebagai suatu kegiatan yang bermanfaat.

Menurut Imam Ghazali dalam kitab Ihya' Ulum ad-din menulis, "Jika pada seseorang anak menonjol akhlak baik dan perbuatan terpujinya, maka ia patut dimuliakan, digembirakan dan dipuji di depan orang banyak untuk memberikan semangat berakhlak mulia dan berbuat terpuji." Memuliakan anak dan memberi semangat dengan hadiah atau dengan ucapan yang manis sesuai dengan sabda Nabi yang diriwayatkan oleh ath-Thabrani, "Saling 
memberi hadiahlah agar kalian saling mencintai". Kalau kita perhatikan karakter siswa semasa sekolah, maka pastilah mereka sangat menyukai apabila dapat penghargaan dari gurunya, baik penghargaan yang sifatnya berwujud maupun tidak berwujud. Karena itu, seorang guru hendaknya merespons apa yang disukai seorang anak. Guru harus bisa memberikan hadiah-hadiah tersebut pada kesempatan yang tepat.

\section{Penutup}

Dari uraian di atas, ada enam hal yang perlu dilakukan Guru untuk menjadikan para Siswa akktif memuat pertanyaa dalam setiap Pembelaran. Pertama Guru paham tentang Kurikulum 2013, kedua Guru perlu melakukan perubahan mindset, ketiga Guru paham tentang Pendekatan saintifik dalam pembelajaran, keempat Guru manpu membuat Kegiatan Pengamatan yang menarik, kelima Guru harus mendorong siswa mau dan mampu menanya, terutama mengajukan pertanyaan yang bersifat investigatif, keenam Guru perlu memahami model-model pembelajaran yang dapat mendukung dalam penerapan pendekatan saintifik. Terakhir Guru harus menerapkan sembilan hal yang dapat diterapkan pada kegiatan bertanya, yaitu (1) Mengenalkan suatu fenomena menarik yang belum pernah dikenali oleh siswa sebelumnya, (2) Words in a question, (3) Guru memberikan contoh pertanyaan pancingan, (4) Guru membentuk kelompok belajar dalam kegiatan pengamatan dan bertanya, (5) Guru dapat juga meminta siswa untuk bekerja dalam kelompok untuk membuat beberapa pertanyaan, (6) Guru mendampingi masing-masing siswa untuk membuat pertanyaan, (7) Completing What if or What if not questions, (8) Questioning Breakfast, dan (9) Questioning Appraisal.

\section{Daftar Pustaka}

1. As'ari, Abdurrahman. 2014. Berbagai Permasalahan Pembelajaran Matematika dalam Kurikulum 2013 dan Beberapa Upaya untuk Mengatasinya. Makalah disajikan dalam Seminar Nasional: Solusi Problematika Implementasi Kurikulum 2013 untuk Mewujudkan Pembelajaran Matematika yang Berkualitas, Program Studi Pendidikan Matematika Universitas Jember, Jember, 16 Maret.

2. As'ari, Abdurrahman. 2015. Mewujudkan Pendekatan Saintifik dalam Kelas Matematika. UM Malang

3. Kemdikbud, 2014. Peraturan Menteri Pendidikan dan Kebudayaan, No. 103, tahun 2014. Jakarta: Kementerian Pendidikan dan Kebudayaan.

4. Kemdikbud. 2015. Materi Pelatihan Guru Implementasi Kurikulum 2013 Jenjang SMP Tahun 2015. Jakarta.

5. Kemdikbud, 2016. Matematika SMP Kelas 7 Edisi Revisi 2016: Buku Siswa. Jakarta: Pusat Kurikulum dan Perbukuan.

6. Kemdikbud, 2016. Matematika SMP Kelas 7 Edisi Revisi 2016: Buku Guru. Jakarta: Pusat Kurikulum dan Perbukuan.

7. Kemdikbud, 2016. Matematika SMP Kelas 8 Edisi Revisi 2016: Buku Siswa. Jakarta: Pusat Kurikulum dan Perbukuan.

8. Laura Bofferding, dkk. 2012. Making Connections Among Student Learning, Content, and Teaching: Teacher Talk Paths in Elementary Mathematics Lesson Study. Journal for Research in Mathematics Education, Vol. 43, No. 5 (November 2012), pp. 616- 650.

9. Tohir, Mohammad. 2014. Analisis Penerapan Kegiatan Pengamatan Buku Siswa Matematika SMP/MTs Kelas VIII Semester 1 Kurikulum 2013 di SMP Islam Sabilillah Malang. SMP Islam Sabilillah Malang.

10. Tohir, Mohammad. 2016. Penerapan Pendekatan Saintifik pada Pembelajaran Matematika Ditinjau dari Sikap Kritis Siswa Kelas VIII MTs Raudlatul Hasanah Pamekasan. MTs Raudlatul Hasanah Pamekasan. 